Marquette University

e-Publications@Marquette

College of Education Faculty Research and

Publications

Education, College of

$1-2013$

\title{
International Advisees' Perspectives on the Advising Relationship in Counseling Psychology Doctoral Programs
}

\author{
Sarah Knox \\ Marquette University, sarah.knox@marquette.edu \\ Justin T. Sokol \\ Arpana G. Inman \\ Lehigh University \\ Lewis Z. Schlosser \\ University of Maryland - College Park \\ Johanna Nilsson
}

See next page for additional authors

Follow this and additional works at: https://epublications.marquette.edu/edu_fac

Part of the Education Commons

\section{Recommended Citation}

Knox, Sarah; Sokol, Justin T.; Inman, Arpana G.; Schlosser, Lewis Z.; Nilsson, Johanna; and Wang, Yu-Wei, "International Advisees' Perspectives on the Advising Relationship in Counseling Psychology Doctoral Programs" (2013). College of Education Faculty Research and Publications. 348.

https://epublications.marquette.edu/edu_fac/348 


\section{Authors}

Sarah Knox, Justin T. Sokol, Arpana G. Inman, Lewis Z. Schlosser, Johanna Nilsson, and Yu-Wei Wang

This article is available at e-Publications@Marquette: https://epublications.marquette.edu/edu_fac/348 
Marquette University

\section{e-Publications@Marquette}

\section{Education Faculty Research and Publications/College of Education}

This paper is NOT THE PUBLISHED VERSION; but the author's final, peer-reviewed manuscript. The published version may be accessed by following the link in the citation below.

International Perspectives in Psychology: Research, Practice, Consultation, Vol. 2, No. 1 (2013): 45-61. DOI. This article is (C) American Psychological Association and permission has been granted for this version to appear in e-Publications@Marquette. American Psychological Association does not grant permission for this article to be further copied/distributed or hosted elsewhere without the express permission from American Psychological Association.

\section{International Advisees' Perspectives on the Advising Relationship in Counseling Psychology Doctoral Programs}

By: Sarah Knox

Department of Counselor Education and Counseling Psychology, College of Education, Marquette University; Justin T. Sokol Department of Counselor Education and Counseling Psychology, College of Education, Marquette University Arpana G. Inman College of Education, Lehigh University

Lewis Z. Schlosser

College of Education and Human Services, Seton Hall University

Johanna Nilsson

School of Education, University of Missouri-Kansas City

Yu-Wei Wang

Department of Psychology, Southern Illinois University-Carbondale

Acknowledgement: Justin T. Sokol is now at the Mayo Clinic, Rochester, MN. Lewis Z. Schlosser is now at the New York City Department of Correction.

As noted by scholars (Gelso, 1979, 1993, 1997; Gelso \& Lent, 2000; Knox, Schlosser, Pruitt, \& Hill, 2006; Schlosser \& Foley, 2008; Schlosser \& Gelso, 2001, 2005; Schlosser \& Kahn, 2007; Schlosser, Knox, Moskovitz, \& Hill, 2003), advising relationships are pivotal to students' experiences in counseling psychology doctoral programs. The advisor-the faculty member bearing the greatest responsibility for guiding advisees through their program-must facilitate advisees' progress, including research requirements, clinical development, career decisions, and professional 
socialization (Schlosser et al., 2003). Despite its importance, scant literature exists in this area; furthermore, only recently has attention been accorded to international students' advising relationships.

\section{Advising International Students}

According to recent data (Institute of International Education [IIE], 2011), there are almost 723,300 international students in the U.S. (an increase of $32 \%$ from 10 years ago), translating to slightly $<4 \%$ of the total college student enrollment. These international students are themselves quite diverse. Based on numbers from the 2010-2011 school year, about 54\% of these students come from China, India, South Korea, Canada, or Taiwan. The majority of these students are enrolled in graduate programs $\underline{(I I E,}$ 2011).

More specific to psychology, and according to the most recent data, approximately $6.5 \%$ of the 5,477 students who received a U.S. doctoral psychology degree in 2008-2009 were nonresident aliens, which includes international students (U.S. Department of Education, National Center for Education Statistics, 2010). Norcross, Evans, and Ellis (2010) reported the proportion of international counseling psychology doctoral students in U.S. APA-accredited programs at 8\%; specific information regarding these students' countries of origin was not available. Likewise, Forrest (2010) reported that international students, most of whom are Asian, comprise $8.2 \%$ of the student body in APA-accredited counseling psychology programs (Park-Saltzman, Wada, \& Mogami, 2012). Thus, a noteworthy percentage of students in counseling psychology doctoral programs is of international origin.

Relatedly, Schlosser and colleagues (Schlosser, Lyons, Talleyrand, Kim, \& Johnson, 2011a, 2011b; Schlosser, Talleyrand, Lyons, Kim, \& Johnson, 2011) recently proposed a multicultural model of advising relationships. They postulated interpersonal (advisor-advisee similarity, support and challenge, role perceptions) and instructional (advising tasks and functions, task-related empathy) components of good advising relationships, asserting that these components have particular salience for students from diverse backgrounds. Interpersonally, advisor-advisee similarity may be assessed via worldview, acculturation, and enculturation; balancing support and challenge relies on the advisor's ability to understand the student's unique needs; role perceptions arise from the racial and cultural socialization experiences of the advisor and advisee. As instructional components, advising tasks and functions may help the advising relationship become a mentorship, which may be especially important for advisees of color, who are more likely than their White counterparts to be first-generation graduate students; in demonstrating task-related empathy, advisors do not force a culturally discrepant worldview onto advisees (e.g., making all advisees work as the advisor does). The authors believe the model appropriate for both international and domestic students, given that they conceptualized the advising relationship as an inherently multicultural endeavor (i.e., just as in therapy, multicultural factors must be considered in all advising relationships). Thus, the model may help explain some of the challenges unique to international students' advising relationships.

Among those challenges, international students may experience acculturative stresses that affect the advising relationship. As international advisees incorporate values, behaviors, and cultural practices of a new culture into those of their culture of origin, for instance, they often encounter conflict between their "original" and their "present" culture (Berry, 1980; Park-Saltzman et al., 2012), tensions that may affect the advising process. 
One challenge faced by many international students, and not likely faced by their domestic peers, is their unfamiliarity with U.S. educational systems and their resulting difficulty with course selection, class attendance, faculty interactions, or grading systems (Meyer, 1995; Mori, 2000; Parr, Bradley, \& Bingi, 1992; Thomas \& Althen, 1989). As students in counseling psychology doctoral programs, their assumptions about human behavior, as well as mental illness and treatment, may also be questioned (Nilsson \& Wang, 2008). Those for whom English is a second language may have difficulty understanding lectures, expressing themselves in class, answering questions on examinations (Meyer, 1995; Mori, 2000; Park-Saltzman et al., 2012; Parr et al., 1992; Thomas \& Althen, 1989), or communicating with domestic therapy clients (Gutierrez, 1982; Inman, Jeong, \& Mori, 2008; Lacina, 2002). Even with English proficiency, international students may not understand the nuances of the contextualized and often nonverbal communication that infuses psychotherapy (Betancourt \& Lopez, 1993; Brown, 2007; Inman et al., 2008; Nilsson \& Wang, 2008; Park-Saltzman et al., 2012; Sodowsky, Lai, \& Plake, 1991). Lower levels of acculturation may also negatively affect international students' counseling self-efficacy (Nilsson \& Anderson, 2004).

Beyond the academic and clinical worlds, cultural differences may affect international students' adjustment and emotional well-being. Culture shock may evoke helplessness, homesickness, loneliness, and mistrust (Oberg, 1979; Pedersen, 1991; Wang, Lin, Pang, \& Shen, 2007). Peers and faculty may hold prejudicial views that threaten adjustment and well-being (Inman et al., 2008; Rahman \& Rollock, 2004; Surdam \& Collins, 1984); relatedly, international students may feel that they do not fit with domestic students (Inman et al., 2008; Killian, 2001), and some also report difficulties connecting with supervisors (Killian, 2001). International students also face career concerns as they decide where to pursue employment postgraduation (Nilsson \& Wang, 2008).

Given such challenges, international students in the U.S. often experience acculturative stress, and the greater the cultural differences between students' native culture and that of the U.S., the more stress they may report (Poyrazli, Arbona, Nora, McPherson, \& Pisecco, 2002). Fortunately, most students' adjustment improves (Hechanova-Alampay, Beehr, Christiansen, \& Van Horn, 2002), with some students becoming more academically engaged (e.g., level of academic challenge, student-faculty interaction) and noting greater gains in personal and social growth than their U.S. counterparts (Zhao, Kuh, \& Carini, 2005). Amid these challenges, the advising relationship is of great import, for it can help international students navigate professional and cultural transitions (Park-Saltzman et al., 2012).

\section{Empirical Literature on Advising International Students}

Using a sample of 367 diverse international graduate students, Rice et al. (2009) found that some working alliance ratings (Rapport, Identification-Individuation) were lower for international students than for U.S. domestic students; were minimally correlated with grade point average, gender, or area of study; but were linked to advising satisfaction. A smaller subsample of 230 students also responded to open-ended questions. The qualitative findings revealed that students (a) characterized poor advising as consisting of inaccessibility, lack of guidance, poor feedback, and excessive demands; (b) noted interpersonal relationship issues, such as advisors being impersonal, unsupportive, disrespectful, and abusive; (c) reported a mismatch of research interests; and (d) cited a lack of financial support as influencing their perceptions of the advising relationship. Although Rice's findings are informative, and the inclusion of open-ended questions welcomed, they do not fully capture international students' 
experiences (Rice et al. asked only three open-ended questions and thus captured limited information in contrast to that gathered by a complete interview protocol). Additionally, participants came from a wide range of academic disciplines, which may likewise have different norms for advising relationships.

Sato and Hodge (2009) focused on six Asian graduate students studying a range of different academic fields in the U.S. Students' language differences adversely influenced their academic experience, created relationship barriers, and required them to become more self-aware. This study's findings are based solely on Asian students not in counseling psychology.

Swagler and Ellis (2003) examined Taiwanese graduate students' cross-cultural adjustment, and found that adjustment was influenced by language barriers, confidence about speaking English, social contact with Taiwanese and Americans, and cultural differences (e.g., the importance of being independent). This study yields intriguing findings, but is limited in its focus on a single national identity and inclusion of students from diverse graduate disciplines.

This extant research, although helpful, exposes crucial gaps in the literature. None specifically addressed counseling psychology doctoral students; two focused only on students of Asian descent; two samples came from a single university, the other from just two universities. We still lack, then, a deep understanding of international counseling psychology doctoral students' experiences of the advising relationship, as informed by participants from multiple universities (Nilsson \& Anderson, 2004; Rice et al., 2009). Furthermore, Schlosser et al.'s (2011a, 2011b; Schlosser, Talleyrand et al., 2011) multicultural theory of advising relationships calls for accompanying empirical examination of such relationships.

\section{Current Study}

We sought to examine international students' perspectives on advising relationships in U.S. counseling psychology doctoral programs. Given our profession's emphasis on multiculturalism and cultural competency, and the proportion of international students in our programs (Forrest, 2010; Norcross et al., 2010), we must understand these students' perspectives on the advising relationship so that we not only teach, but also model, cultural competency. Our research questions were as follows: To provide context for our central focus on participants' advising experiences, we first asked about participants' overall experiences as international students. We then asked about their experiences of their advising relationship, the primary focus of the study. Finally, we asked what advice they would give international students, as well as their advisors, regarding advising international students.

We chose a qualitative method to access students' experiences without restricting their responses. Specifically, we used consensual qualitative research (CQR; Hill et al., 2005; Hill, Thompson, \& Williams, 1997), in which a small number of cases are deeply explored to reach a keen understanding of a phenomenon, data analysis occurs through consensual group process, and findings emerge inductively from the data. Auditors review the consensus judgments to verify their grounding in the data. 


\section{Method}

\section{Participants}

Advisees

Ten international students from at least seven different U.S.-based doctoral programs (we do not know the doctoral programs from which some participants came) in counseling psychology (seven women, three men) participated in this study, and ranged from 24 to 34 years old $(M=29.70, S D=3.80)$. Nine identified Asian countries of origin. Racially, six identified as Asian, one as Chinese, one as Taiwanese, and one as White (one did not answer this question); the salience of their racial identification ( $1=$ low, $10=$ high) was $M=8.38, S D=1.69$ (Range $=5-10)$. As national identification, three identified as Chinese, two as Malaysian, two as Taiwanese, one as Canadian, one as Chilean, and one as Japanese; the salience of their national identification was $M=8.11, S D=2.09$ (Range $=4-10$ ). As cultural/ethnic identification, two identified as Asian, two as Chinese, one as Chinese/Malaysian, one as Japanese, one as Latina/Hispanic, one as Malay, one as Taiwanese, and one as Taiwanese/Chinese; the salience of their cultural/ethnic identification was $M=7.67, S D=1.00$ (Range $=6-9$ ). These students had been in the U.S. for $M=5.90, S D=3.21$ (Range $=1-12$ ) years, and in their doctoral program for $M=2.20, S D=$ 1.32 (Range $=1-5$ ) years. Seven self-reported their English proficiency as good and three as excellent; four had previously earned an undergraduate and six a graduate degree from a U.S. institution. They had been working with their current advisor for $M=1.85, S D=1.11$ (Range = 1-4) years; two met weekly, three met biweekly, one met monthly, two met bimonthly, one met twice a year, and one met "whenever necessary" with their advisor, for between $30 \mathrm{~min}$ and $3 \mathrm{~h}(M=1.05, S D=.71 \mathrm{~h})$.

\section{Advisors}

Participants described their advisors (six female, three male [one did not answer this question]) as ranging in age from their mid 30 s to their mid $60 \mathrm{~s}(M=54.70, S D=10.53)$. Nine were identified as being from the U.S., one from Taiwan; nine were identified racially/ethnically as White, one as Taiwanese. As reported by participants, their advisors had $M=20.70, S D=10.68$ (Range $=2-30+$ ) years of doctoral advising experience, currently advised $M=1.00, S D=1.05$ (Range $=0-3$ ) other international doctoral students, and had $M=4.80, S D=2.44$ (Range $=2-10$ ) total other advisees.

Interviewers and judges

Four researchers interviewed participants and served as judges (i.e., analyzers of data) on the primary team. Two were female counseling psychology associate professors (a 49-year-old European American, a 48-year-old South Asian Indian), one was a 38-year-old Ashkenazi American Jewish male counseling psychology associate professor, and one was a 27-year-old male European American doctoral student in counseling psychology. A 45-year-old White, Swedish, female associate professor in counseling psychology and a 36-year-old Taiwanese/Chinese female assistant professor in counseling psychology served as auditors. All but the graduate student had previous experience with CQR; the graduate student was thoroughly trained in CQR before and during participation in the study.

With regard to the authors' relevant experiences and biases, all reported positive relationships with their doctoral advisors, three had been international students in graduate psychology, and all had experience working with international students, whether as advisees, students, supervisees, or peers. Two researchers were uncertain what to expect from participants' responses to the protocol, three anticipated that advisors would be an important connection for international students during their 
program, and three felt that international students would have mixed experiences with advisors. The researchers monitored these biases by internally reflecting and by openly questioning each other during data analysis.

\section{Measures}

\section{Demographic form}

We asked for age, gender, country of origin, racial identity, national identity, cultural/ethnic identity, and any other salient identities. Participants were also asked to rate the salience of each identity $(1=$ low, 10 = high). In addition, they reported their year in doctoral program, length of time in the U.S., level of English proficiency, prior degree(s) earned in the U.S., duration of advising relationship, and frequency/length of advising meetings. Participants also provided information about their advisor: age, gender, country of origin, race/ethnicity, years of doctoral advising experience, total number of international advisees other than the participant, and total number of advisees other than the participant.

Interview protocol

Using the research questions noted earlier as a guide, all researchers collaboratively developed the protocol, working through several iterations before arriving at the final version. The resulting protocol was piloted on three nonparticipant volunteers who met the participation criteria, and then slightly modified based on their feedback. In the resulting semistructured protocol, each participant answered a standard set of questions (e.g., overall experiences as an international student; relationship with advisor; discussion with advisor of experiences as an international student; how being an international student affected advising relationship; advice for international students and their advisors), and researchers pursued additional areas based on participant answers. The complete protocol appears in the Appendix.

\section{Procedures for Collecting Data}

\section{Recruiting participants}

We cast a wide net to recruit participants (listservs of professional organizations [e.g., American Psychological Association (APA) of Graduate Students; Asian American Psychological Association (AAPA); Division 17 (Counseling Psychology) of APA: Section on Ethnic and Racial Diversity, Special Interest Group on Mentoring International Students; Division 52 (International Psychology) of APA; Society for Psychotherapy Research; South Asian Psychological Network Association (SAPNA); Association for Women in Psychology (AWP); Taiwan Psychology Network (TPN)], contacting colleagues/students for snowball sampling). The electronic postings provided information about the study and participation criteria (adults who were currently international students enrolled in a U.S.based counseling psychology doctoral program, who had been working with their current advisor for at least one academic year, and who had not yet defended their dissertation), as well as the primary investigator's contact information. The researchers' professional contacts received similar descriptions of the study and were asked to share the information with appropriate persons in their own professional networks. All interested individuals contacted the primary investigator, who e-mailed the demographic and consent forms, and the interview protocol. The protocol was sent so that potential participants could reflect on the questions they would be asked and give fully informed consent. After 
receiving the completed forms, a primary team member contacted the participant and scheduled the first interview. All who completed the forms participated in the study.

Interviewing and transcribing

Each member of the primary team conducted the initial and follow-up audiotaped phone interviews with two or three participants. At the end of the 45-60-min initial interview, the interviewer arranged for the follow-up interview for approximately two weeks later and before data analysis of that case. The follow-up interview enabled interviewers and participants to clarify any areas in question or to elaborate on responses from the first interview (e.g., if an area seemed unclear or incomplete, interviewer/-ee could reexamine the area in the follow-up interview). Participants known to a researcher were interviewed by a team member without such an affiliation; their data were also analyzed by team members with no such affiliation. All interviews were transcribed verbatim (other than minimal encouragers, silences, or stutters). Any identifying information was deleted, and each participant was given a code number to protect confidentiality.

\section{Procedures for Analyzing Data}

Data were analyzed in accordance with CQR (Hill et al., 1997, 2005), a rigorous and well-known qualitative method in the U.S. In CQR, researchers reach consensus by discussing data classification and interpretation as they engage in the three steps of analysis (domain coding, during which data are organized into topic areas; core ideas, in which the team creates abstracts for the data in each domain for each participant to capture their essence; cross-analysis, during which the team examines core ideas within each domain but across cases to arrive at categories that capture common themes); two auditors reviewed each step. Each participant received by e-mail a draft of the study's results and was asked to ensure that her/his confidentiality had been maintained. Any comments (e.g., clarifications) received were incorporated into the manuscript.

Quality and trustworthiness were established via several means: The researchers challenged each others' analysis and interpretation of the data, and queried each other with regard to the potential influence of their biases; all judges had an equal voice; one judge had herself been an international student; two external auditors reviewed all data analysis; participants reviewed the draft of the manuscript.

\section{Results}

We followed CQR guidelines ( $\mathrm{Hill}$ et al., 2005) in labeling category frequencies: Categories that emerged for all or all but one case $(N=9-10)$ were considered general, those that emerged for more than half of the cases $(N=6-8)$ were considered typical, and those that emerged for at least two and up to half of the cases $(N=2-5)$ were considered variant; findings that arose in a single case were placed into an "other" category and are not reported. To preserve space, we present here only domains and categories; illustrative core ideas appear in Table 1. In addition, we provide a running composite example depicting the general and typical results. To protect confidentiality, we created the composite example by using findings from a number of different cases. 
Table 1

\begin{tabular}{|c|c|c|}
\hline Domain/Category & Frequency & Illustrative core idea(s) \\
\hline \multicolumn{3}{|l|}{$\begin{array}{l}\text { Overall experiences as international } \\
\text { students }\end{array}$} \\
\hline \multicolumn{3}{|l|}{ Challenges } \\
\hline Academic & Typical & $\begin{array}{l}\text { P had to learn to navigate U.S. educational system; } \\
\text { expectations of students different in U.S. versus P's } \\
\text { home country }\end{array}$ \\
\hline Adjustment/Acculturation & Typical & $\begin{array}{l}\text { Hard for P to conform to U.S. roles/behaviors because } \\
\text { P feels less acculturated; East Coast culture more } \\
\text { fast-paced, competitive, aggressive, less friendly, so } \\
\text { harder for P to adapt and interact; new experiences } \\
\text { stressful (size of trees in U.S.) }\end{array}$ \\
\hline Language & Typical & $\begin{array}{l}\text { Mixed feelings about being given more time on projects } \\
\text { due to language proficiency; at times P has problem } \\
\text { expressing herself or making herself understood in } \\
\text { English; P afraid of being laughed at because of "bad } \\
\text { English" }\end{array}$ \\
\hline $\begin{array}{l}\text { Others not understanding } P \\
\text { experience/culture }\end{array}$ & Typical & $\begin{array}{l}\text { Feels that professors have no idea how much IS are } \\
\text { doing; feels that others often do not understand P and } \\
\text { her feelings, or are "not on the same page" as P }\end{array}$ \\
\hline $\begin{array}{l}\text { Lack of social support/being } \\
\text { away from family }\end{array}$ & Typical & $\begin{array}{l}\mathrm{P} \text { is lonely and misses family and friends from home; } \\
\text { feels disconnected and wishes that more U.S. students } \\
\text { reached out to IS to help them cope, include them in } \\
\text { activities }\end{array}$ \\
\hline Financial & Variant & $\begin{array}{l}\text { Doesn't have access to much financial aid; frustrated } \\
\text { that not able to support self through doctoral studies } \\
\text { because of IS status }\end{array}$ \\
\hline Discrimination & Variant & $\begin{array}{l}\text { Some faculty have double-standards about IS (assume } \\
\text { that IS don't understand U.S. culture); supervisor told } \\
\text { P that P "still thinking like a (P ethnicity)" }\end{array}$ \\
\hline \multicolumn{3}{|r|}{ 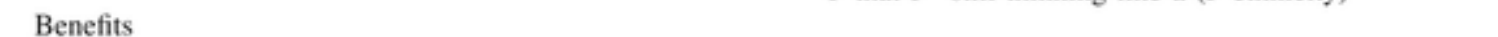 } \\
\hline Professional/Personal growth & Typical & $\begin{array}{l}\text { P developed inner strength and got to know self better; } \\
\text { being IS has expanded }\end{array}$ \\
\hline \multicolumn{3}{|l|}{ Environment for IS in program } \\
\hline Not culturally receptive & General & \\
\hline Faculty & Typical & $\begin{array}{l}\text { Faculty assume that IS have same abilities/qualities as } \\
\text { U.S. students and treat them equally ("color-blind"), } \\
\text { and by doing so, faculty assume that they are being } \\
\text { "good faculty"; advisors "pretend to be multicultural } \\
\text { but they are not"; P felt he was learning to be less of } \\
\text { his own culture, but then felt faculty view was that P } \\
\text { shouldn't be doing that (should not be less his own } \\
\text { culture) }\end{array}$ \\
\hline Peers & Variant & $\begin{array}{l}\text { Caucasian students mingle only among themselves and } \\
\text { it's hard for P to start conversations with them; U.S. } \\
\text { students do not show genuine interest or desire to } \\
\text { make friends with IS }\end{array}$ \\
\hline Program & Variant & $\begin{array}{l}\text { P's program not very diverse and does not have many } \\
\text { IS; program says they welcome and value different } \\
\text { perspectives that IS bring, but P doesn't feel it }\end{array}$ \\
\hline Culturally receptive & Typical & \\
\hline Program & Typical & $\begin{array}{l}\text { Program receptive to IS; program starting in-depth } \\
\text { orientation for incoming students to process } \\
\text { stereotype and diversity issues; because are more IS } \\
\text { in program now. P feels strong sense of community }\end{array}$ \\
\hline Peers & Variant & $\begin{array}{l}\text { P feels integrated by other IS; P's peers understand and } \\
\text { discuss cross-cultural issues openly }\end{array}$ \\
\hline
\end{tabular}

\section{Findings}




\begin{tabular}{|c|c|c|}
\hline Domain/Category & Frequency & Illustrative core idea(s) \\
\hline Faculty & Variant & $\begin{array}{l}\text { Some faculty are welcoming, share information, invite P } \\
\text { to home; P thinks faculty are welcoming and } \\
\text { genuinely curious to understand IS perspectives and } \\
\text { cultures P worldview }\end{array}$ \\
\hline $\begin{array}{l}\text { The advising relationship } \\
\text { How participant began to work } \\
\text { with advisor }\end{array}$ & & \\
\hline $\begin{array}{l}\text { Matched based on shared } \\
\text { interests }\end{array}$ & Typical & $\begin{array}{l}\text { P shared advisor's research interests, so was matched } \\
\text { when started program }\end{array}$ \\
\hline $\begin{array}{l}\text { Assigned to advisor when } \\
\text { started program }\end{array}$ & Typical & P was assigned to advisor by program \\
\hline $\begin{array}{l}\text { P researched potential advisor } \\
\text { for fit } \\
\text { Relationship with advisor }\end{array}$ & Typical & $\begin{array}{l}\mathrm{P} \text { identified faculty with shared research interests, } \\
\text { contacted them during application/admission process }\end{array}$ \\
\hline
\end{tabular}

General

General

$\begin{array}{lc}\text { Advisor accessible } & \text { Typical } \\ \text { Advisor respectful } & \text { Variant } \\ \begin{array}{l}\text { Similarities enhanced } \\ \text { relationship }\end{array} & \text { Variant } \\ & \\ \begin{array}{l}\text { Advisor's past international } \\ \text { experiences made } P\end{array} & \text { Variant } \\ \text { comfortable } & \\ \begin{array}{l}\text { Formal/Professional rx, } \\ \text { which felt comfortable }\end{array} & \\ \text { Negative elements } & \text { Variant } \\ \text { Advisor occasionally not } & \\ \text { supportive/accessible } & \text { Variant }\end{array}$

Discussion with advisor about being IS

Discussed adjustment/being Typical away from home

Discussed role of culture in therapy/research

Variant
Advisor emphasizes P's adjustment to environment and feeling comfortable as grad student; advisor helped P during difficulty with stats professor; P could not believe advisor was so supportive of P's pursuit of clinical work, even when advisor not tenured; advisor shares "everything she has" and students a priority for advisor

Advisor available (in person, e-mail) and regularly meets with P; P can call advisor any time; advisor responds quickly

Advisor respectful of P's ideas and of $\mathrm{P}$ as person; advisor respects and supports P's choice to pursue practice and do minimal research

Advisor does not work nights or weekends due to family commitments, which fits with P's values; speaking same (non-English) language as advisor opens up conversation

$\mathrm{P}$ knew advisor had IS advisees in past, which made $\mathrm{P}$ comfortable; advisor has traveled overseas, is openminded about relationship, and "really understands diversity, different cultures, different values and beliefs"

$\mathrm{P}$ has good professional relationship with advisor but not a personal relationship; relationship not like a "buddy" but is good

P once wished advisor had provided more emotional support during difficult time, but $\mathrm{P}$ wonders if wanting emotional support is asking too much; $\mathrm{P}$ does not have good relationship with advisor $-\mathrm{P}$ frustrated, felt that advisor did not understand P, had different expectations about relationship than $\mathrm{P}$ had, $\mathrm{P}$ felt stuck and unable to change advisors even though advisor not meeting $\mathrm{P}$ needs

Talked with advisor about P's support system because advisor knows that P living alone; talked about challenges of being IS; occasionally talk about P's adjustment to U.S. culture

$\mathrm{P}$ and advisor have talked about how therapy is viewed differently in different countries and how culture affects therapy and training 


\begin{tabular}{|c|c|c|}
\hline Domain/Category & Frequency & Illustrative core idea(s) \\
\hline Minimal/No discussion & Variant & $\begin{array}{l}\text { P's advisor was an IS, so P feels they both understand } \\
\text { P's difficulties and need not discuss; advisor did not } \\
\text { ask P about P being IS, so P wondered if advisor } \\
\text { even wanted to know }\end{array}$ \\
\hline \multicolumn{3}{|l|}{$\begin{array}{l}\text { Impact of P's international status } \\
\text { on relationship }\end{array}$} \\
\hline $\begin{array}{c}\text { Advisor gave more attention/ } \\
\text { was culturally sensitive }\end{array}$ & Variant & $\begin{array}{l}\text { P feels P got more attention and care than other } \\
\text { students, feels advisor wanted to protect P, cares } \\
\text { about P, wanted to ensure that P adjusted well; } \\
\text { advisor more careful and conscious about P's cultural } \\
\text { background, tries to build relationship because } \\
\text { advisor has no experience with IS }\end{array}$ \\
\hline Negative effects & Variant & $\begin{array}{l}\text { Relationship sometimes awkward because advisor and } \mathrm{P} \\
\text { exert more effort since relationship doesn't come } \\
\text { naturally; P wonders if } \mathrm{P} \text { being different race/culture } \\
\text { has negative impact on relationship, and felt that } \\
\text { advisor did not understand where } \mathrm{P} \text { coming from, } \\
\text { what } \mathrm{P} \text { needed }\end{array}$ \\
\hline No effect & Variant & $\begin{array}{l}\mathrm{P} \text { does not think IS status affected relationship; } \mathrm{P} \text { being } \\
\text { IS did not change relationship }\end{array}$ \\
\hline \multicolumn{3}{|l|}{ Unique needs from advisor } \\
\hline Social/Emotional support & Typical & $\begin{array}{l}\text { Crucial for advisors to know that IS lack social } \\
\text { connections because away from home and may } \\
\text { distract IS from schoolwork; need someone to } \\
\text { understand what it feels like to be first-generation } \\
\text { (ethnicity) college student, needs someone who } \\
\text { understands what P experiencing; need tolerance from } \\
\text { advisor regarding challenges arising from cultural } \\
\text { differences (difficulty being assertive) }\end{array}$ \\
\hline $\begin{array}{l}\text { Help navigating academicl } \\
\text { professional environment }\end{array}$ & Typical & $\begin{array}{l}\text { Information about IS job-seeking, } \\
\text { internships/externships, career prospects at home; } \\
\text { guidance about academic culture (research, } \\
\text { publishing, conferences) of future faculty member }\end{array}$ \\
\hline Help with language & Variant & $\begin{array}{l}\text { Recognize that English not P's strength; help } \\
\text { overcoming challenges of conducting therapy in } \\
\text { English }\end{array}$ \\
\hline No unique needs & Variant & $\begin{array}{l}\mathrm{P} \text { did not think there were any unique needs in graduate } \\
\text { work }\end{array}$ \\
\hline \multicolumn{3}{|l|}{$\begin{array}{l}\text { Advice borne of experiences as } \\
\text { international students } \\
\text { Advice for IS }\end{array}$} \\
\hline $\begin{array}{l}\text { Open communication with } \\
\text { advisor }\end{array}$ & General & $\begin{array}{l}\text { Don't make decisions without discussing with advisor; } \\
\text { be assertive, take initiative, be proactive and tell } \\
\text { advisor what you need; realize that advisors may } \\
\text { need the IS to help them understand the IS }\end{array}$ \\
\hline $\begin{array}{l}\text { Seek good rx/match with } \\
\text { advisor }\end{array}$ & Typical & $\begin{array}{l}\text { Build a good relationship with advisor; good to have } \\
\text { similar career goals as advisor; pick the right advisor }\end{array}$ \\
\hline Develop good $r x$ with others & Variant & $\begin{array}{l}\text { Articulate your needs and get support from others; } \\
\text { important to find allies on your side (people you can } \\
\text { trust and rely on); if plan to stay in U.S., build } \\
\text { relationships with Americans }\end{array}$ \\
\hline $\begin{array}{l}\text { Prepare self before entering } \\
\text { doctoral program }\end{array}$ & Variant & $\begin{array}{l}\text { Do master's degree in U.S. first, to provide transition } \\
\text { before moving on to doctoral program; use } \\
\text { opportunities on campus to improve English } \\
\text { proficiency since it's critical in psychology and in } \\
\text { doctoral program; know the culture before you come } \\
\text { to U.S. }\end{array}$ \\
\hline
\end{tabular}


Table 1 (continued)

\begin{tabular}{|c|c|c|}
\hline Domain/Category & Frequency & Illustrative core idea(s) \\
\hline \multicolumn{3}{|l|}{ Advice for advisors of IS } \\
\hline $\begin{array}{c}\text { Understand/Attend to IS } \\
\text { culture/challenges }\end{array}$ & General & $\begin{array}{l}\text { Make extra effort to get to know IS advisee, her/his } \\
\text { cultural background; recognize that IS face obstacles } \\
\text { that differ from U.S. students, so attend to and have } \\
\text { empathy for those; show concern for IS academic and } \\
\text { personal life; be sensitive, humble, don't assume that } \\
\text { you know it all; be open, responsive, and sensitive to } \\
\text { cultural and background differences; realize that IS } \\
\text { may need more support }\end{array}$ \\
\hline
\end{tabular}

Note. $\quad N=10 ;$ General $=9-10$ cases; Typical $=6-8$ cases; Variant $=2-5$ cases.

IS = International Student; $\mathrm{P}=$ Participant; $\mathrm{Rx}=$ relationship.

Table 1: Findings

\begin{tabular}{|c|c|c|}
\hline Domain/Category & Frequency & Illustrative core idea(s) \\
\hline \multicolumn{3}{|l|}{$\begin{array}{l}\text { Overall experiences as } \\
\text { international students }\end{array}$} \\
\hline \multicolumn{3}{|l|}{ Challenges } \\
\hline Academic & Typical & $\begin{array}{l}\text { P had to learn to navigate U.S. educational system; } \\
\text { expectations of students different in U.S. versus P's } \\
\text { home country }\end{array}$ \\
\hline Adjustment/Acculturation & Typical & $\begin{array}{l}\text { Hard for P to conform to U.S. roles/behaviors } \\
\text { because P feels less acculturated; East Coast culture } \\
\text { more fast-paced, competitive, aggressive, less } \\
\text { friendly, so harder for P to adapt and interact; new } \\
\text { experiences stressful (size of trees in U.S.) }\end{array}$ \\
\hline Language & Typical & $\begin{array}{l}\text { Mixed feelings about being given more time on } \\
\text { projects due to language proficiency; at times P has } \\
\text { problem expressing herself or making herself } \\
\text { understood in English; P afraid of being laughed at } \\
\text { because of "bad English" }\end{array}$ \\
\hline $\begin{array}{l}\text { Others not understanding } \\
P \text { experience/culture }\end{array}$ & Typical & $\begin{array}{l}\text { Feels that professors have no idea how much IS are } \\
\text { doing; feels that others often do not understand P } \\
\text { and her feelings, or are "not on the same page" as P }\end{array}$ \\
\hline $\begin{array}{l}\text { Lack of social } \\
\text { support/being away from } \\
\text { family }\end{array}$ & Typical & $\begin{array}{l}\text { P is lonely and misses family and friends from home; } \\
\text { feels disconnected and wishes that more U.S. } \\
\text { students reached out to IS to help them cope, } \\
\text { include them in activities }\end{array}$ \\
\hline Financial & Variant & $\begin{array}{l}\text { Doesn't have access to much financial aid; frustrated } \\
\text { that not able to support self through doctoral } \\
\text { studies because of IS status }\end{array}$ \\
\hline Discrimination & Variant & $\begin{array}{l}\text { Some faculty have double-standards about IS } \\
\text { (assume that IS don't understand U.S. culture); } \\
\text { supervisor told P that P "still thinking like a (P } \\
\text { ethnicity)" }\end{array}$ \\
\hline \multicolumn{3}{|l|}{ Benefits } \\
\hline $\begin{array}{l}\text { Professional/Personal } \\
\text { growth }\end{array}$ & Typical & $\begin{array}{l}\text { P developed inner strength and got to know self } \\
\text { better; being IS has expanded }\end{array}$ \\
\hline
\end{tabular}




\begin{tabular}{|c|c|c|}
\hline Environment for IS in program & & \\
\hline Not culturally receptive & General & \\
\hline Faculty & Typical & $\begin{array}{l}\text { Faculty assume that IS have same abilities/qualities } \\
\text { as U.S. students and treat them equally ("color- } \\
\text { blind"), and by doing so, faculty assume that they } \\
\text { are being "good faculty"; advisors "pretend to be } \\
\text { multicultural but they are not"; P felt he was } \\
\text { learning to be less of his own culture, but then felt } \\
\text { faculty view was that P shouldn't be doing that } \\
\text { (should not be less his own culture) }\end{array}$ \\
\hline Peers & Variant & $\begin{array}{l}\text { Caucasian students mingle only among themselves } \\
\text { and it's hard for P to start conversations with them; } \\
\text { U.S. students do not show genuine interest or desire } \\
\text { to make friends with IS }\end{array}$ \\
\hline Program & Variant & $\begin{array}{l}\text { P's program not very diverse and does not have } \\
\text { many IS; program says they welcome and value } \\
\text { different perspectives that IS bring, but P doesn't } \\
\text { feel it }\end{array}$ \\
\hline Culturally receptive & Typical & \\
\hline Program & Typical & $\begin{array}{l}\text { Program receptive to IS; program starting in-depth } \\
\text { orientation for incoming students to process } \\
\text { stereotype and diversity issues; because are more IS } \\
\text { in program now, P feels strong sense of community }\end{array}$ \\
\hline Peers & Variant & $\begin{array}{l}\text { P feels integrated by other IS; P's peers understand } \\
\text { and discuss cross-cultural issues openly }\end{array}$ \\
\hline Faculty & Variant & $\begin{array}{l}\text { Some faculty are welcoming, share information, } \\
\text { invite } \mathrm{P} \text { to home; } \mathrm{P} \text { thinks faculty are welcoming and } \\
\text { genuinely curious to understand IS perspectives and } \\
\text { cultures } \mathrm{P} \text { worldview }\end{array}$ \\
\hline \multicolumn{3}{|l|}{ The advising relationship } \\
\hline \multicolumn{3}{|l|}{$\begin{array}{l}\text { How participant began to } \\
\text { work with advisor }\end{array}$} \\
\hline $\begin{array}{l}\text { Matched based on shared } \\
\text { interests }\end{array}$ & Typical & $\begin{array}{l}\text { P shared advisor's research interests, so was } \\
\text { matched when started program }\end{array}$ \\
\hline $\begin{array}{l}\text { Assigned to advisor when } \\
\text { started program }\end{array}$ & Typical & P was assigned to advisor by program \\
\hline $\begin{array}{l}P \text { researched potential } \\
\text { advisor for fit }\end{array}$ & Typical & $\begin{array}{l}\text { P identified faculty with shared research interests, } \\
\text { contacted them during application/admission } \\
\text { process }\end{array}$ \\
\hline \multicolumn{3}{|l|}{ Relationship with advisor } \\
\hline Positive elements & General & \\
\hline Advisor supportive & General & $\begin{array}{l}\text { Advisor emphasizes P's adjustment to environment } \\
\text { and feeling comfortable as grad student; advisor } \\
\text { helped P during difficulty with stats professor; P } \\
\text { could not believe advisor was so supportive of P's } \\
\text { pursuit of clinical work, even when advisor not }\end{array}$ \\
\hline
\end{tabular}




\begin{tabular}{|c|c|c|}
\hline & & $\begin{array}{l}\text { tenured; advisor shares "everything she has" and } \\
\text { students a priority for advisor }\end{array}$ \\
\hline Advisor accessible & Typical & $\begin{array}{l}\text { Advisor available (in person, e-mail) and regularly } \\
\text { meets with P; P can call advisor any time; advisor } \\
\text { responds quickly }\end{array}$ \\
\hline Advisor respectful & Variant & $\begin{array}{l}\text { Advisor respectful of } \mathrm{P}^{\prime} \text { s ideas and of } \mathrm{P} \text { as person; } \\
\text { advisor respects and supports } \mathrm{P}^{\prime} \mathrm{s} \text { choice to pursue } \\
\text { practice and do minimal research }\end{array}$ \\
\hline $\begin{array}{l}\text { Similarities enhanced } \\
\text { relationship }\end{array}$ & Variant & $\begin{array}{l}\text { Advisor does not work nights or weekends due to } \\
\text { family commitments, which fits with P's values; } \\
\text { speaking same (non-English) language as advisor } \\
\text { opens up conversation }\end{array}$ \\
\hline $\begin{array}{l}\text { Advisor's past } \\
\text { international experiences } \\
\text { made P comfortable }\end{array}$ & Variant & $\begin{array}{l}\text { P knew advisor had IS advisees in past, which made } \\
\text { P comfortable; advisor has traveled overseas, is } \\
\text { openminded about relationship, and "really } \\
\text { understands diversity, different cultures, different } \\
\text { values and beliefs" }\end{array}$ \\
\hline $\begin{array}{l}\text { Formal/Professional } r x \\
\text { which felt comfortable }\end{array}$ & Variant & $\begin{array}{l}\text { P has good professional relationship with advisor but } \\
\text { not a personal relationship; relationship not like a } \\
\text { "buddy" but is good }\end{array}$ \\
\hline Negative elements & Variant & \\
\hline $\begin{array}{l}\text { Advisor occasionally not } \\
\text { supportive/accessible }\end{array}$ & Variant & $\begin{array}{l}\text { P once wished advisor had provided more emotional } \\
\text { support during difficult time, but } P \text { wonders if } \\
\text { wanting emotional support is asking too much; } P \\
\text { does not have good relationship with advisor-P } \\
\text { frustrated, felt that advisor did not understand } P \text {, } \\
\text { had different expectations about relationship than } P \\
\text { had, } P \text { felt stuck and unable to change advisors even } \\
\text { though advisor not meeting } P \text { needs }\end{array}$ \\
\hline \multicolumn{3}{|l|}{$\begin{array}{l}\text { Discussion with advisor } \\
\text { about being IS }\end{array}$} \\
\hline $\begin{array}{l}\text { Discussed } \\
\text { adjustment/being away } \\
\text { from home }\end{array}$ & Typical & $\begin{array}{l}\text { Talked with advisor about P's support system } \\
\text { because advisor knows that P living alone; talked } \\
\text { about challenges of being IS; occasionally talk about } \\
\text { P's adjustment to U.S. culture }\end{array}$ \\
\hline $\begin{array}{l}\text { Discussed role of culture } \\
\text { in therapy/research }\end{array}$ & Variant & $\begin{array}{l}\mathrm{P} \text { and advisor have talked about how therapy is } \\
\text { viewed differently in different countries and how } \\
\text { culture affects therapy and training }\end{array}$ \\
\hline Minimal/No discussion & Variant & $\begin{array}{l}\text { P's advisor was an IS, so P feels they both } \\
\text { understand P's difficulties and need not discuss; } \\
\text { advisor did not ask P about P being IS, so P } \\
\text { wondered if advisor even wanted to know }\end{array}$ \\
\hline $\begin{array}{l}\text { Impact of P's international } \\
\text { status on relationship }\end{array}$ & & \\
\hline
\end{tabular}




\begin{tabular}{|c|c|c|}
\hline $\begin{array}{l}\text { Advisor gave more } \\
\text { attention/ was culturally } \\
\text { sensitive }\end{array}$ & Variant & $\begin{array}{l}\text { P feels } P \text { got more attention and care than other } \\
\text { students, feels advisor wanted to protect } P \text {, cares } \\
\text { about } P \text {, wanted to ensure that } P \text { adjusted well; } \\
\text { advisor more careful and conscious about } P^{\prime} \text { s } \\
\text { cultural background, tries to build relationship } \\
\text { because advisor has no experience with IS }\end{array}$ \\
\hline Negative effects & Variant & $\begin{array}{l}\text { Relationship sometimes awkward because advisor } \\
\text { and } \mathrm{P} \text { exert more effort since relationship doesn't } \\
\text { come naturally; } \mathrm{P} \text { wonders if } \mathrm{P} \text { being different } \\
\text { race/culture has negative impact on relationship, } \\
\text { and felt that advisor did not understand where } \mathrm{P} \\
\text { coming from, what } \mathrm{P} \text { needed }\end{array}$ \\
\hline No effect & Variant & $\begin{array}{l}\text { P does not think IS status affected relationship; P } \\
\text { being IS did not change relationship }\end{array}$ \\
\hline \multicolumn{3}{|l|}{ Unique needs from advisor } \\
\hline Social/Emotional support & Typical & $\begin{array}{l}\text { Crucial for advisors to know that IS lack social } \\
\text { connections because away from home and may } \\
\text { distract IS from schoolwork; need someone to } \\
\text { understand what it feels like to be first-generation } \\
\text { (ethnicity) college student, needs someone who } \\
\text { understands what P experiencing; need tolerance } \\
\text { from advisor regarding challenges arising from } \\
\text { cultural differences (difficulty being assertive) }\end{array}$ \\
\hline $\begin{array}{l}\text { Help navigating } \\
\text { academic/ professional } \\
\text { environment }\end{array}$ & Typical & $\begin{array}{l}\text { Information about IS job-seeking, } \\
\text { internships/externships, career prospects at home; } \\
\text { guidance about academic culture (research, } \\
\text { publishing, conferences) of future faculty member }\end{array}$ \\
\hline Help with language & Variant & $\begin{array}{l}\text { Recognize that English not P's strength; help } \\
\text { overcoming challenges of conducting therapy in } \\
\text { English }\end{array}$ \\
\hline No unique needs & Variant & $\begin{array}{l}\mathrm{P} \text { did not think there were any unique needs in } \\
\text { graduate work }\end{array}$ \\
\hline \multicolumn{3}{|l|}{$\begin{array}{l}\text { Advice borne of experiences as } \\
\text { international students }\end{array}$} \\
\hline \multicolumn{3}{|l|}{ Advice for IS } \\
\hline $\begin{array}{l}\text { Open communication } \\
\text { with advisor }\end{array}$ & General & $\begin{array}{l}\text { Don't make decisions without discussing with } \\
\text { advisor; be assertive, take initiative, be proactive } \\
\text { and tell advisor what you need; realize that advisors } \\
\text { may need the IS to help them understand the IS }\end{array}$ \\
\hline $\begin{array}{l}\text { Seek good } r x / \text { match with } \\
\text { advisor }\end{array}$ & Typical & $\begin{array}{l}\text { Build a good relationship with advisor; good to have } \\
\text { similar career goals as advisor; pick the right advisor }\end{array}$ \\
\hline $\begin{array}{l}\text { Develop good } r x \text { with } \\
\text { others }\end{array}$ & Variant & $\begin{array}{l}\text { Articulate your needs and get support from others; } \\
\text { important to find allies on your side (people you can } \\
\text { trust and rely on); if plan to stay in U.S., build } \\
\text { relationships with Americans }\end{array}$ \\
\hline
\end{tabular}




\begin{tabular}{|c|l|l|}
\hline $\begin{array}{l}\text { Prepare self before } \\
\text { entering doctoral } \\
\text { program }\end{array}$ & Variant & $\begin{array}{l}\text { Do master's degree in U.S. first, to provide transition } \\
\text { before moving on to doctoral program; use } \\
\text { opportunities on campus to improve English } \\
\text { proficiency since it's critical in psychology and in } \\
\text { doctoral program; know the culture before you } \\
\text { come to U.S. }\end{array}$ \\
\hline Advice for advisors of IS & General \\
\hline $\begin{array}{l}\text { Understand/Attend to IS } \\
\text { culture/challenges }\end{array}$ & $\begin{array}{l}\text { Make extra effort to get to know IS advisee, her/his } \\
\text { cultural background; recognize that IS face obstacles } \\
\text { that differ from U.S. students, so attend to and have } \\
\text { empathy for those; show concern for IS academic } \\
\text { and personal life; be sensitive, humble, don't } \\
\text { assume that you know it all; be open, responsive, } \\
\text { and sensitive to cultural and background differences; } \\
\text { realize that IS may need more support }\end{array}$ \\
\hline
\end{tabular}

Note. $\quad \mathrm{N}=10$; General $=9-10$ cases; Typical $=6-8$ cases; Variant $=2-5$ cases. IS = International Student; $\mathrm{P}=$ Participant; $\mathrm{Rx}=$ relationship.

\section{Overall Experiences as International Students}

As context for the findings specifically addressing participants' advising relationships, the primary focus of the study, we first present findings describing participants' overall experiences as international students.

Challenges of being an international student

Participants typically reported a number of challenges: academic difficulties; struggles with adjustment/acculturation; difficulties with language; challenges of others not understanding their experience or culture; and lack of social support, including being away from family. They variantly noted financial challenges and incidents of discrimination.

Benefits of being an international student

Although fewer different types of benefits emerged, in comparison with the challenges noted above, participants did typically report that a benefit of being an international student was professional and/or personal growth (enhanced inner strength, improved self-knowledge, expanded worldview).

Environment for international students in doctoral program

On one hand, participants generally found the environment in their doctoral program not culturally receptive. Specifically, they typically found faculty not receptive, and variantly found peers and the program as a whole not receptive. On the other hand, and in seeming contradiction, participants typically also described the environment as culturally receptive. Specifically, they typically described the program as receptive, and variantly stated that peers and faculty were receptive.

In our composite example, Adele (pseudonym) was a 31-year-old Asian female who had been in the U.S. for 6 years. She had recently completed the second year of her doctoral program, after having earned a master's degree in counseling from a different U.S.-based institution. She described her proficiency in English as good. She had been working with her advisor for 2 years; they met three to four times a month for about an hour each time. Their advising meetings focused mostly on research, 
but also attended to Adele's questions about program requirements and her well-being in the program. Adele's advisor, Dr. P (pseudonym), was a 52-year-old, White, European American, female counseling psychology faculty member with 15 years of doctoral advising experience. In the past, she had advised four international students, and currently had a total advising load of five students.

Adele acknowledged that she had encountered some challenges during her doctoral program. The "unknown expectations and new experiences" were stressful for her, and she had heard that "professors like students to speak in class," which differed from her culture of origin. Adele was afraid, however, that others would not understand her and would judge her, or that she would "look stupid," so having to talk in class exacerbated her stress, especially early in her program. During her first two years, she also struggled to build relationships with her U.S. cohort/peers, and attributed this difficulty, at least in part, to their not fully understanding each other's cultures. She noted, as well, that "living in a place that is not familiar and (is) away from family," who were her main support, was also challenging. Nevertheless, Adele noted that she "is more confident in herself now," has become more independent, and eventually developed a stronger social network. In addition, she became "part of a bigger community of international students" in her area, and thus immersed herself in diversity, which "enriched (her) professional development."

Adele noted that the broader environment for international students in her program was often not culturally responsive. She stated that they sometimes "feel forgotten about" by faculty, especially those who "do not understand diversity." At times, however, the program did feel culturally receptive, such as when Adele felt supported for needing to go home, or when the program intentionally interviewed more international students in their final admissions process, which yielded a more diverse student body.

\section{The Advising Relationship}

How participant began to work with advisor

Three typical categories emerged here: With equal frequency, participants were matched with their advisors based on shared interests; were assigned to their advisor upon entering their doctoral program; or actively researched potential advisors for goodness of fit, and then began to work with those so identified when entering the program.

\section{Relationship with advisor}

\section{Positive elements}

In general, participants noted positive features of their advising relationship. More specifically, they generally described their advisor as supportive, typically found her/him to be accessible, and variantly reported their advisor as respectful. In addition, participants variantly stated that similarities between themselves and their advisor enhanced the relationship, that their advisors' previous international experiences (e.g., with previous international students or with international travel) made them feel more comfortable, and that the formal professional relationship they had with their advisor was comfortable.

\section{Negative elements}

Variantly, negative features of the advising relationship emerged. Specifically, participants variantly found their advisor occasionally not supportive or accessible. 
Discussion with advisor about participant being an international student

Typically, participants and advisors discussed the formers' process of adjusting to being away from home. They variantly discussed the role of culture in therapy or research, and also variantly reported minimal or no discussion related to their being an international student.

Impact of participants' international student status on advising relationship Variantly, participants reported that their being an international student led their advisor to give them increased attention and to be culturally sensitive. They also variantly noted that their being an international student had negative effects on the relationship (e.g., awkwardness), and also variantly reported that their international student status had no effect on the relationship.

Unique needs from advisor as an international student

Typically, participants stated that as an international student, their unique needs included a desire for social or emotional support from their advisor, and also typically a desire for help from their advisor to navigate the academic and professional environment. Variantly, they noted unique needs involving help with language, and reported that they had no unique needs as an international student.

Continuing the composite example, Adele stated that she was matched with Dr. P when she was admitted to the program because they shared research interests. She noted that when she applied to the program, she "expressed interest in working with (Dr. P) because of their matching interests" and because Adele admired Dr. P's work.

Now having worked with Dr. P for a few years, Adele described their advising relationship quite positively. Adele "feels lucky and proud" to have Dr. P as her advisor, feels that Dr. P is empathic and that Adele can share anything with her, and feels that Dr. P genuinely cares about Adele and has provided the support that Adele needed the most. Dr. P is also very responsive to e-mails, gives good feedback in a timely manner, and schedules frequent advising meetings with Adele. Adele did not report any significant negative features of their relationship. She and Dr. P have occasionally talked about Adele's adjustment to the program and her being so far away from home, with Dr. P empathically acknowledging, "I can't imagine what it is like for you as an international student" to be far away from home and to have left your family for the doctoral program.

When asked if she had any unique needs of her advisor as an international student, Adele indicated that she wanted "to be able to address both (her) academic and personal life" and to feel "validated by her advisor" with regard to understanding her experiences of being an international student. In addition, she sought from Dr. P assistance in becoming familiar with the U.S. educational system, as well as information regarding how she might be able to stay in the U.S. to work postgraduation if she wished to do so.

\section{Advice Borne of Participants' Experiences as International Student}

Advice for international students Participants generally advised international students to communicate openly with their advisor, and typically to seek a good relationship and match with their advisor. They variantly recommended that international students develop good relationships with others, as well, and variantly advised them to prepare themselves before entering a doctoral program (e.g., complete their master's degree in the U.S.). 
Advice for advisors of international students

Participants generally recommended that advisors of international students understand and attend to international students' culture and the challenges of being an international doctoral student.

Returning to Adele, she urged international students "not to be afraid to speak their mind" with their advisor, even though doing so may feel rude or culturally inappropriate. Instead, international students should recognize that "people in the U.S. are more casual in their social interactions and less restricted compared to some other cultures," and thus international students "need to be able to step out of their boundaries... be more open and express (their) concerns." Similarly, she stated that international students cannot "expect (advisors) to know what you want unless you tell them." Furthermore, she recommended that international students "try to connect and build a personal relationship" with their advisor, not just an academic relationship, so that they feel more comfortable with their advisor because "it is important to like and really trust (your) advisor."

Finally, Adele urged advisors of international students to "try to put themselves in their international students'/advisees' shoes," to convey that you care about your international student advisee, to learn about her/his cultural background, and to make an effort to understand the challenges your advisee may encounter as an international student. Likewise, advisors of international students need to "be open to new things and different opinions" from those whose cultural background differs from that of the advisor, and to "ask (their international student advisees) if they are having any problems." In addition, advisors should "advocate for their international student advisee, should create an environment where (their international student advisee) feels comfortable and at ease being in the program."

\section{Discussion}

What is the story that these findings tell? First addressing the contextual findings, these international students noted more challenges than benefits, in both the professional and personal realms, areas also echoed in their unique needs. Although the literature parallels these results (Betancourt \& Lopez, 1993; Brown, 2007; Gutierrez, 1982; Inman et al., 2008; Lacina, 2002; Meyer, 1995; Mori, 2000; Oberg, 1979; Parr et al., 1992; Pedersen, 1991; Sato \& Hodge, 2009; Sodowsky et al., 1991; Swagler \& Ellis, 2003; Thomas \& Althen, 1989), we remain surprised that participants reported so few benefits to themselves of being international students. Given the opportunity to study in another country, to interact with those different from themselves (Hechanova-Alampay et al., 2002; Inman et al., 2008; Zhao et al., 2005), we are concerned that these opportunities seemed to translate into comparatively fewer rewards. Perhaps such benefits only emerge after time, or are overshadowed by the immediate challenges of training. Or perhaps training programs are not yet fully sensitive to the needs of international students.

The findings related to program environments are also worrisome, for the program is the context within which the advising relationship exists. Although most participants indeed noted program components that were culturally receptive to international students, many also noted components of that environment that were not culturally receptive. Those students who may be most vulnerable, whose needs may differ from or exceed those of domestic students, often seem to find their training environment less than ideal. Whether (based on our participants' experiences) referring to faculty who 
assume what international students do/do not need, how international students should/should not behave, or from peers not integrating international students into their interactions and activities, these findings are troubling, and are not unique (Killian, 2001; Rahman \& Rollock, 2004; Surdam \& Collins, 1984). Perhaps it is no surprise, then, that fewer participants noted rewards of being an international student.

Now moving to the primary focus of the study, participants' largely positive advising relationships were pivotal, a finding also reflected in literature on domestic U.S. students (Gelso, 1979, 1993, 1997; Gelso \& Lent, 2000; Inman et al., 2011; Knox et al., 2006; Schlosser \& Foley, 2008; Schlosser \& Gelso, 2001; Schlosser \& Kahn, 2007; Schlosser et al., 2003). Comparatively few negative features of the advising relationship emerged; those that were noted parallel Rice et al.'s findings (2009). Thus, advisors' support and guidance appear key to both domestic and international students' experiences in their doctoral program, supporting the interpersonal and instructional components of the theory of multicultural advising recently proposed by Schlosser and colleagues (Schlosser et al., 2011a, 2011b; Schlosser, Talleyrand et al., 2011).

We cannot ignore, however, the few participants who noted negative elements of their advising relationship. Did advisors' perceived lack of support arise from cultural misunderstandings or insensitivity; from acculturation-related tensions; from (as proposed by Schlosser and colleagues' multicultural model of advising) too much challenge and too little support, inconsistent role perceptions, too little task-related empathy? We duly acknowledge that these advisors may form poor relationships with domestic students, as well, due to lack of time, lack of skills, or lack of investment. It is also possible that their international student advisees struggled academically or clinically, which likely puts additional stress on the relationship. Furthermore, perhaps these participants entered the advising relationship with different expectations than their advisors (regarding advisor accessibility; openness to a more personal relationship; provision of concrete advice, guidance, and information [Park-Saltzman et al., 2012]; or the academic challenges of a U.S. doctoral program), which, if unfulfilled, led them to characterize their advising relationship negatively.

These international students reported some conversation with advisors about being international students, but the discussions seemed neither frequent nor deep. Rather, such interactions occurred occasionally (e.g., advisor and international student beginning their relationship; international students whose first language is not English having difficulty with English-speaking clients). Given that many participants came from cultures that value respect toward (Sue \& Sue, 2008) and indirect communication with those in authority (Park-Saltzman et al., 2012), we wonder whether they hesitated to initiate such discussions and instead waited for their advisor to do so. If the advisor did not broach the topic, did the discussion ever occur? And who is responsible for initiating these conversations? We argue that advisors' possession of more formal power gives them greater responsibility for initiating conversations about advisees' experiences being an international student. Advisors can thereby nurture environments in which international students feel validated and understood, and may eventually initiate difficult discussions on their own, even though doing so may run counter to their own culture's norms.

We were surprised that participants perceived that their being international students had little impact on the advising relationship, especially because the mean ratings of racial, national, and cultural/ethnic 
identifications were high. Perhaps, continuing the theme of respect for authority, participants did not bring their international student status into the relationship, and instead waited for advisors to do so, letting them indicate whether such content was appropriate, consistent with the assertions of ParkSaltzman et al. (2012). If such conversations remained infrequent and superficial, international students may not have emphasized that part of themselves in the relationship, thus reducing its potential overt impact. It may also be that these students' tenure in the U.S. for almost six years rendered such conversations less necessary or salient. Furthermore, even though programs may communicate a commitment to multiculturalism, that commitment may emphasize ethnic and racial diversity more than the diversity that international students bring. Another possibility is that participants did not want their international student status to be perceived as burdensome (using the words of Schlosser et al.[2011a, 2011b; Schlosser, Talleyrand et al., 2011], they wanted to preserve advisor-advisee similarity), and did not speak about how being an international student affected the relationship, thereby enabling them to maintain harmony in the relationship and save face (ParkSaltzman et al., 2012).

In response to their experiences, these international students urged other international students to communicate openly and build good relationships with advisors, even when direct communication may not be consistent with advisees' cultural norms (Park-Saltzman et al., 2012). They likewise urged advisors to sensitively attend to their international students, support them with the challenges of being an international student, get to know them as international students, as advisees, as full human beings, echoing the suggestions of Inman et al. (2008), as well as the multicultural theory of advising relationships posited by Schlosser and colleagues (Schlosser et al., 2011a, 2011b; Schlosser, Talleyrand et al., 2011). Relatedly, Park-Saltzman et al. (2012) also recommended that advisors examine the potential impact of their own beliefs and assumptions on their relationships with their international advisees.

What, then, is this study's contribution to the literature? First, international students, who comprise approximately $8 \%$ of the counseling psychology doctoral student population in APA-accredited programs (Forrest, 2010; Norcross et al., 2010), may experience more challenges than rewards in U.S.based counseling psychology doctoral programs, challenges that encompass the academic/professional and personal arenas (or, to use the language of Schlosser and colleagues, the instructional and interpersonal components). Such challenges may exist in other professional psychology programs as well (e.g., clinical psychology, school psychology). These challenges may increase the demands on or expectations of these students' advisors, especially when international students lack social support and family access. Thus, the degree to which advisors understand these advisees' acculturative stresses and recognize their efforts to adjust to the dominant culture may play a vital role in international students' experiences of the advising relationship. Second, the doctoral program environment was frequently perceived by these international students as not culturally receptive, a troubling finding, given the internationalization of the field. Third, just as with domestic students, the advising relationship is key to international students' experiences in their program. If that relationship falters, such tension may be particularly problematic for international students. Fourth, although some discussion between international students and advisors about the formers' international student status does occur, it seems neither to happen frequently nor be pursued deeply. Finally, these participants' status as 
international students had minimal overt impact on the advising relationship, a puzzling finding worthy of further investigation.

\section{Limitations}

Although we sought broad representation, this sample consisted primarily of international students with at least some Asian descent. We note, however, that more than half of the international students in the U.S. come from Asian countries (IIE, 2011), and also that the majority of international students in counseling psychology doctoral programs are of Asian heritage (Park-Saltzman et al., 2012).

Nevertheless, we do not know how the experiences of international students without this heritage may differ. Seven participants were women; although consistent with counseling psychology program demographics, a gender-balanced sample may yield different findings. Participants had been in the U.S. almost 6 years, all reported English proficiency as at least good, and several had previously earned a degree (four an undergraduate degree and six a graduate degree) from a U.S. institution. International students with less time in the U.S., less proficiency in English, or less familiarity with U.S. educational systems may report different experiences. We also cannot discern what portion of participants' positive or negative experiences may be attributable to influences beyond the advising relationship (e.g., familiarity with U.S. culture or U.S. academic culture). We have only our participants' perspectives, and relied on their ability to describe events in what may not be their primary language; furthermore, the demographic information they provided about their advisors was not confirmed by the advisors themselves. We also do not have data regarding advisors racial/ethnic identities. Participants received the protocol before agreeing to be in the study; those who saw the protocol but chose not to take part may have had different experiences. Although receiving the protocol in advance may influence what participants share in the interview (e.g., eliciting social desirability), it also allows participants to provide fully informed consent and enables them to reflect on their experiences prior to the interview, thereby facilitating rich and detailed responses. Finally, we did not inquire about participants' comfort level with the interviewer as they discussed their experiences.

\section{Implications for Training}

Advisors should consistently attend to international students' professional and personal welfare, as well as their unique needs (e.g., language issues that may arise in practicum training, understanding of cultural norms and nuances; Park-Saltzman et al., 2012). We may imperil any benefits that such advisees receive from their international student experience, and also their success in the program, if we do not invite regular and substantial conversations about international students' experiences. It is also vital that advisors and advisees discuss, early in their relationship, the responsibilities and role expectations of each (Park-Saltzman et al., 2012). As earlier noted, such discussions may alleviate advisees' acculturative stress, and may also bolster the formation and maintenance of the relationship that Schlosser and colleagues (Schlosser et al., 2011a, 2011b; Schlosser, Talleyrand et al., 2011) assert is central to the advising process. Such conversations may also be prudent during the selection and admissions process: Potential advisors and advisees sharing their expectations of the advising relationship may reduce the likelihood of future conflicts and misunderstandings. Periodically "taking the temperature" of the relationship may therefore be especially prudent when advisor and advisee come from different cultures, for their differing backgrounds may engender miscommunication. Furthermore, we recommend that advisors ask their international students about their experiences as 
international students, and invite them to present to their peers about their specific cultural frameworks. Advisors opening up such topics may communicate to international students that such conversations are welcome, and may likewise forge a stronger advising bond.

On a broader (i.e., program or university) level, we urge faculty to examine the messages conveyed about multiculturalism. Does the term primarily connote race and ethnicity, or does it include internationalism? Are there mechanisms in place to support international students and foster their successful completion of the program and a more receptive training environment (e.g., formal and informal opportunities to meet with faculty and students and thereby build social support, international faculty and students on campus, offices on campus that serve international students, presence of international residents in the surrounding community)? Wrestling with this question may ameliorate the unreceptive program environment that participants reported.

Clearly, the training environment consists of more than the advising relationship. Program environments are, in fact, quite complex and contain multiple components, few of which likely elicit a purely receptive or nonreceptive characterization. Thus, although the advising relationship is admittedly key, it exists within a larger context that also warrants attention from those who inhabit that environment.

\section{Implications for Research}

We heard students' voices; we lack advisors' perspectives, surely an important component. Our sample was primarily female and Asian, and many had earned a degree at a U.S. university; we need to know how men, as well as non-Asian international students and those without a U.S.-based degree, experience their advising relationship. We could also ask international students what programs can do to reduce the challenges and increase the benefits of being international counseling psychology doctoral students, and what would render programs more culturally receptive. Similarly, we remain curious about the finding that participants' international student status seemed not to overtly affect the advising relationship. Finally, examination of international students' experiences of the advising relationship in clinical and school psychology doctoral programs would also provide useful information.

\section{References}

Berry, J. W. (1980). Acculturation as varieties of adaptation. In A. M.Padilla (Ed.), Acculturation: Theory, models and some new findings (pp. 9-25). Colorado: Westview Press.

Betancourt, H., \& Lopez, S. R. (1993). The study of culture, ethnicity, and race in American psychology. American Psychologist, 48, 629-637.

Brown, H. D. (2007). Principles of language learning and teaching (5th ed.). San Francisco, CA: Pearson \& Longman.

Forrest, L. (2010). Linking international psychology, professional competence, and leadership: Counseling psychologist as learning partners. The Counseling Psychologist, 38, 96-120.

Gelso, C. J. (1979). Research in counseling: Methodological and professional issues. The Counseling Psychologist, 8, 7-35.

Gelso, C. J. (1993). On the making of a scientist-practitioner: A theory of research training in professional psychology. Professional Psychology: Research and Practice, 24, 468-476. 
Gelso, C. J. (1997). The making of a scientist in applied psychology: An attribute by treatment conception. The Counseling Psychologist, 25, 307-320.

Gelso, C. J., \& Lent, R. W. (2000). Scientific training and scholarly productivity: The person, the training environment, and their interaction. In S. D.Brown \& R. W.Lent (Eds.), Handbook of counseling psychology (3rd ed., pp. 109-139). New York: Wiley.

Gutierrez, F. J. (1982). Working with minority counselor education students. Counselor Education and Supervision, 3, 218-226.

Hechanova-Alampay, R., Beehr, T. A., Christiansen, N. D., \& Van Horn, R. K. (2002). Adjustment and strain among domestic and international student sojourners: A longitudinal study. School Psychology International, 23, 458-474.

Hill, C. E., Knox, S., Thompson, B. J., Nutt Williams, E., Hess, S. A., \& Ladany, N. (2005). Consensual qualitative research: An update. Journal of Counseling Psychology, 52, 196-205.

Hill, C. E., Thompson, B. J., \& Williams, B. N. (1997). A guide to conducting consensual qualitative research. The Counseling Psychologist, 25, 517-572.

Inman, A. G., Jeong, J. Y., \& Mori, Y. (2008). Benefits and challenges of studying psychology in the United States. In N. T.Hasan, N. A.Fouad, \& C.Williams-Nickelson (Eds.), Studying psychology in the United States: Expert guidance for international students (pp. 25-35). Washington, DC: APA Books.

Inman, A. G., Schlosser, L. Z., Ladany, N., Howard, E. E., Boyd, D. L., Altman, A., \& Stein, E. P. (2011). Advisee nondisclosures in advising relationships. Training and Education in Professional Psychology, 5, 149-159.

Institute of International Education. (2011). Open doors: Report on international educational exchange. New York: Institute of International Education.

Killian, K. D. (2001). Differences making a difference: Cross-cultural interactions in supervisory relationships. Journal of Feminist Family Theory, 12, 61-103.

Knox, S., Schlosser, L. Z., Pruitt, N. T., \& Hill, C. E. (2006). A qualitative examination of graduate advising relationships: The advisor perspective. The Counseling Psychologist, 34, 489-518.

Lacina, J. G. (2002). Preparing international students for a successful social experience in higher education. New Directions for Higher Education, 117, 21-28.

Meyer, L. (1995). Academic acculturation for foreign graduate students: Meeting new concepts of research and writing. College ESL, 5, 83-91.

Mori, S. (2000). Addressing the mental health concerns of international students. Journal of Counseling and Development, 78, 137-144.

Nilsson, J. E., \& Anderson, M. Z. (2004). Supervising international students: The role of acculturation, role ambiguity, and multicultural discussions. Professional Psychology: Research and Practice, 35, 306-312.

Nilsson, J. E., \& Wang, C-C. D. C. (2008). Supervising international students in counseling and psychology training. In A. K.Hess, K. D.Hess, \& T. H.Hess (Eds.), Psychotherapy supervision: Theory, research, and practice (pp. 70-81). Hoboken, NJ: Wiley.

Norcross, J. C., Evans, K. L., \& Ellis, J. L. (2010). The model does matter II: Admissions and training in APA-accredited counseling psychology programs. The Counseling Psychologist, 38, 257-268. 
Oberg, K. (1979). Culture shock and the problem of adjustment in new cultural environments. In E. C.Smith \& L. F.Luce (Eds.), Toward internationalism: Readings in cross-cultural communication. Rowley, MA: Newbury House.

Park-Saltzman, J., Wada, K., \& Mogami, T. (2012). Culturally sensitive mentoring for Asian international students in counseling psychology. The Counseling Psychologist, 40, 895-915.

Parr, G., Bradley, L., \& Bingi, R. (1992). Concerns and feelings of international students. Journal of College Student Development, 33, 20-25.

Pedersen, P. B. (1991). Counseling international students. The Counseling Psychologist, 19, 10-58.

Poyrazli, S., Arbona, C., Nora, A., McPherson, R., \& Pisecco, S. (2002). Relation between assertiveness, academic self-efficacy, and social adjustment among international graduate students. Journal of College Student Development, 43, 632-641.

Rahman, O., \& Rollock, D. (2004). Acculturation, competence, and mental health among South Asians in the United States. Journal of Multicultural Counseling and Development, 32, 130-142.

Rice, K. G., Choi, C.-C., Zhang, Y., Villegas, J., Ye, H. J., Anderson, D., . . Bigler, M. (2009). International student perspectives on graduate advising relationships. Journal of Counseling Psychology, 56, 376-391.

Sato, T., \& Hodge, S. R. (2009). Asian international doctoral students' experiences at two American universities: Assimilation, accommodation, and resistance. Journal of Diversity in Higher Education, 2, 136-148.

Schlosser, L. Z., \& Foley, P. F. (2008). Ethical issues in multicultural student-faculty mentoring relationships in higher education. Mentoring and Tutoring: Partnership in Learning, 16, 63-75.

Schlosser, L. Z., \& Gelso, C. J. (2001). Measuring the working alliance in advisor-advisee relationships in graduate school. Journal of Counseling Psychology, 48, 157-167.

Schlosser, L. Z., \& Gelso, C. J. (2005). The advisory working alliance inventory-advisor version: Scale development and validation. Journal of Counseling Psychology, 52, 650-654.

Schlosser, L. Z., \& Kahn, J. H. (2007). Dyadic perspectives on advisor-advisee relationships in counseling psychology doctoral programs. Journal of Counseling Psychology, 54, 211-217.

Schlosser, L. Z., Knox, S., Moskovitz, A. R., \& Hill, C. E. (2003). A qualitative study of the graduate advising relationship: The advisee perspective. Journal of Counseling Psychology, 50, 178-188.

Schlosser, L. Z., Lyons, H. Z., Talleyrand, R. M., Kim, B. S. K., \& Johnson, W. B. (2011a). Advisor-advisee relationships in graduate training programs. Journal of Career Development, 38, 3-18.

Schlosser, L. Z., Lyons, H. Z., Talleyrand, R. M., Kim, B. S. K., \& Johnson, W. B. (2011b). A multiculturallyinfused model of graduate advising relationships. Journal of Career Development, 38, 44-61.

Schlosser, L. Z., Talleyrand, R. M., Lyons, H. Z., Kim, B. S. K., \& Johnson, W. B. (2011). Multicultural issues in graduate advising relationships. Journal of Career Development, 38, 19-43.

Sodowsky, G. R., Lai, E. W., \& Plake, B. S. (1991). Moderating effects of sociocultural variables on acculturation attitudes of Hispanics and Asian Americans. Journal of Counseling and Development, 70, 194-204.

Sue, D. W., \& Sue, D. (2008). Counseling the culturally diverse: Theory and practice (5th ed.). New York: Wiley.

Surdam, J. C., \& Collins, J. R. (1984). Adaptation of international students: A cause for concern. Journal of College Student Personnel, 25, 240-245. 
Swagler, M. A., \& Ellis, M. V. (2003). Crossing the distance: Adjustment of Taiwanese graduate students in the United States. Journal of Counseling Psychology, 50, 420-437.

Thomas, K., \& Althen, G. (1989). Counseling foreign students. In P. B.Pedersen, J. C.Draguns, W. J.Lonner, \& J. E.Trimble (Eds.), Counseling across cultures (3rd ed., pp. 205-241). Honolulu: University of Hawaii Press.

U.S. Department of Education, National Center for Education Statistics. (2010). 2008-09 Integrated Postsecondary Education Data System (IPEDS), Fall. 2010.

Wang, Y.-W., Lin, J. G., Pang, L.-S., \& Shen, F. C. (2007). International students from Asia. In F. T.Leong, A. G.Inman, A.Ebrero, L.Yang, L. M.Kinoshita, \& M.Fu (Eds.), Handbook of Asian American Psychology (2nd ed., pp. 245-261). Thousand Oaks, CA: Sage.

Zhao, C.-M., Kuh, G. D., \& Carini, R. M. (2005). A comparison of international student and American student engagement in effective educational practices. Journal of Higher Education, 76, 209231.

\section{APPENDIX}

\section{APPENDIX A: Interview Protocol}

Thank you for your interest in our study of international advisees' perspectives on the advising relationship in counseling psychology doctoral programs. We believe that the relationship between advisors and advisees is extremely important, and may be even more important to international students. Thus, we are grateful for your gift of time to this project. For the purposes of this interview, we ask you to focus on your experiences as an international advisee in your doctoral program. As you do so, please focus on your relationship with the one faculty member with whom you worked most closely (i.e., the person most responsible for your progress through the program). Please be assured, as well, that your responses will be kept confidential.

1. Please tell me a bit about your experiences as an international student overall.

2. How did you come to work with your advisor?

3. How would you describe your relationship with your advisor?

4. As an international student:

- How have you and your advisor discussed your experiences as an international student?

- What are your unique needs in your relationship with your graduate advisor?

- How has being an international student affected your advising relationship?

- What is your perception of the experience of international students in your program?

5. Advice:

- What advice would you give incoming international graduate students concerning the advising relationship?

- What advice would you give advisors of international graduate students concerning the advising relationship?

6. Is there anything else you would like to tell me about your advising relationship?

\section{Closing Questions}

7. What was it like for you to do this interview?

8. Why did you choose to participate in this study? 
